\title{
GLOBAL CITIZENSHIP LEVELS OF POLISH UNIVERSITY STUDENTS AND TURKISH ERASMUS STUDENTS IN POLAND
}

\author{
Kadir Karatekin, Muhammed Hayati Taban
}

\begin{abstract}
The aim of this study is to compare global citizenship levels of Polish university students and Turkish Erasmus students in Poland. To this end, the survey method was employed. The fieldwork was carried out in Warsaw, Krakow and Rzeszow. The study tries to answer two common hypotheses and the answers provide an unanticipated result for European framework and a supportive one for the relation between study abroad experience and global citizenship. The study has significant implications for the effect of education abroad experience on global citizenship
\end{abstract}

Key words: global citizenship, study abroad, Poland, Turkish Erasmus students

\section{Introduction}

World scale events, World War I, II and The Cold War hadn't been experienced yet when Kant wrote 'Peoples of the world, in narrower or wider circles, have now advanced everywhere so far that a violation of Right in one place of the earth, is felt all over it.' (Kant 2010) in his Perpetual Peace: A Philosophical Sketch. Additionally, mass migration wasn't a threatening issue and the world hadn't been shrunk temporally and spatially as it is now. The time we are living right now is conceptualized its epochal concepts which can be dated back to Kant while some may date cosmopolitan citizenship to Cicero basing on his dualistic citizenship view (citizens of the city and citizens of the world) (Nussbaum 1997). On the other hand most contemporary thinkers (Robertson 1992; Albrow 1996; Held 1999 and Held 2002; Delantry 2000; Beck 2003 and 2005; Baumann 2011; Giddens 2013) call it as 'global age'. In this global age, conventional conceptualizations and approaches of 'national' and 'international', 'domestic' and 'foreign politics', 'society' and 'state' have started to lose their power to overcome current problems (Beck 2003). At this point, citizenship concept defined on national basis has come under question recently. The concept defined by Kant (2010) as 'world citizenship' has now different definitions; 'cosmopolitan citizenship' (Linklater, 1998; Hutchings and Dannreuthe 1999), 'post-national citizenship' (Soysal 1998; Tambini 2001; Sassen 2002; Basok 2004), 'global citizenship' (Folk 1993; Lagos 2001; Dower and Williams 2003; Armstrong 2006; Morais and Ogden 2011).

Like all social sciences terms/concepts it is difficult to give an exact definition for global citizenship, but giving dimensions and subdimensions of the concept may help to understand what is implied for global citizenship. Not because will this study use the scale of Morais and Ogden (2011) but because they reach at this scale by analysing and constructing global citizenship literature, the global citizenship framework will be referred to them. Morais and Ogden (2011) determined 3 dimensions for the global citizenship: Social Responsibility, Global Competence and Global Civic Engagement. Here, social responsibility covers these subdimensions: global justice and disparities; altruism and empathy; global interconnectedness and personal responsibility. Global competence dimension is also composed of self-awareness, intercultural communication and global knowledge. Finally, global civic engagement dimension includes involvement in civic organizations, political voice and global civic 
activism. Therefore, it can be understood that global citizenship has 3 dimensions which imply Knowledge, Competence and Action respectively.

After the definition of global citizenship, it is better to know how the citizenship concept evolved. To understand the historical perspective of citizenship evolution, Levels of governance and citizenship by Muetzelfeldt and Smith (2002) who develops Turner's (1997) model on citizenship is worth remembering at this point.

Table 1. Levels of governance and citizenship (Muetzefeldt and Smith 2002)

\begin{tabular}{|l|l|l|l|}
\hline System of governance & $\begin{array}{l}\text { Socio-political } \\
\text { Personhood }\end{array}$ & $\begin{array}{l}\text { Key rights and } \\
\text { obligations }\end{array}$ & $\begin{array}{l}\text { Example of relevant } \\
\text { organized institution }\end{array}$ \\
\hline City-state & Denizen & $\begin{array}{l}\text { Legal rights and } \\
\text { obligations }\end{array}$ & Jury system \\
\hline Nation-state & Citizen & $\begin{array}{l}\text { Political rights and } \\
\text { obligations }\end{array}$ & Parliament \\
\hline Welfare state & Social citizen & $\begin{array}{l}\text { Social rights and } \\
\text { obligations }\end{array}$ & Social welfare agencies \\
\hline Global governance & Global citizen & $\begin{array}{l}\text { Global rights and } \\
\text { obligations }\end{array}$ & $\begin{array}{l}\text { Global institutions, for } \\
\text { example, UN system }\end{array}$ \\
\hline
\end{tabular}

Just as in 17th century denizens of city states were detached from cities, and attached to modern concepts of territorial reign, the same thing happening now can be considered for nation state- citizen status (Linklater 1998). From economic perspective, transnational conflicts stemming from neoliberal policies of second half of 20th century have started to produce discontents in business life, politics and daily life of people. In a nutshell, the necessity to discuss citizenship concept in a global scale is awaiting over there.

On the other hand, there are scholars like Miller (1999) and Neff (1999) who emphasize national base of citizenship concept and criticize global citizenship as the citizenship concept has legal definitions. Dower (2000), as an answer to this kind of criticisms, claims that there are things to be done as a global citizenship without depending on a legal regulation such as acting in a way to influence policies of one's government, joining NGOs or activities aiming at national policies in favour of global issues. That is to say, there is no use pitting global citizenship, which is not defined and framed clearly, to national citizenship which is formed clearly. That's why, it's worth remembering that global citizenship can be a strong instrument to deter people from believing interests of one's own society is superior to that of others (Linklater 1998). Indeed, if someone resists to inequalities stemming from global integration and anti-democratic tendencies by joining a NGO working for global aims (Armstrong 2006), she/he can be considered as a global citizen in both moral and structural terms (Dower 2000).

Regarding educational perspective of global citizenship, it is beneficial to remember the progressivist Kantian thought on cosmopolitanism that focuses on dialogue and consent in place of force and power (Linklater and Suganami 2006). Here, education is considered to be one of the ways to achieve this end because it has already been started to be defined and thought in a global scale (Kniep 1986, Pike 2000, Osler and Vincent 2004, Standish, 2014). According to Alger and Harf (1985); global education enables people to make decisions by considering the binding effect of economic, social, political, military and natural diversity phenomenon. Global education is also seen as an answer to the questions existing in any part of the world and affecting our daily lives such as source scarcity, population explosion, environmental crises, arms race, refugee flows, terrorism, human rights and inflation (Alger and Harf 1985).

Today, study abroad experience is seen as one of the dimensions of global education. Morais and Ogden goes further and presupposes the link between study abroad and global citizenship while developing a global citizenship scale that aims to measure the effect of study abroad experience on global citizenship (Morais and Ogden 2011). Scholars like Lang also accept that study abroad experience is one of the best ways to create global minds (Lang 2013). It is believed that study abroad contributes to global learning and development process by realizing responsibilities beyond one's own 
society, and thus helps to adopt attitudes towards changing his/her behaviours and decisions (Braskamp et.al. 2009; Schatte 2009; Perry et.al. 2013, Samra 2007).

Since its coming into being, the European Union (EU) refers to citizenship a meaning going beyond nation (Linklater 1998; Tambini 2001). The EU has not only affected citizenship but also has shaped and defined all official institutions and relations of the member states. Education is one of these institutions and relations that was re defined and re shaped by the EU. And Erasmus student exchange programme launched by the EU has become one the widest range of study abroad programmes.

The programme launched in 1987 with 3.000 students and $11 \mathrm{EU}$ members, now it covers 34 countries (28 EU member plus Iceland, Lichtenstein, Norway, Switzerland, Turkey, Macedonia) and 3.3 million students (European Commission 2015). In 2014, 213.789 students participated and 600.000 Euro was spent for the student exchange (European Commission 2014a). It should be noted that Erasmus and European identity relationship has been thoroughly studied in the literature; Maiworm (2001), King and Ruiz (2003), Fernandez (2005), Mithcell (2012, 2014), Van Mol (2009), Papatsiba (2009), Wilson (2011), Kuhn (2012). Not only scholars did attribute importance to the programme, but EU citizens see it one of best outcomes of the Union (European Commission 2014b).

The EU and Erasmus student exchange programme are considered to contribute to global citizenship thanks to their contribution to people's global knowledge, competence and actions abilities; thus, it is of utmost importance to test their effect on global citizenship. First aim of the study is inspired from this point of view and this will serve to understand which group (one that have the EU citizenship for over 10 years and one that have an study abroad experience) have a better global citizenship level. While putting an end to their global citizenship scale development article, Morais and Ogden (2011) make a recommendation on using the scale for Erasmus programme (Morais and Ogden 2011). Inspired also from this recommendation, the second aim of the study can be put forward as: to compare global citizenship levels of Turkish Erasmus students in Poland as a non EU member citizen in Poland to that of Polish university students as citizens of EU member country since 2004. Though there have been various studies on Turkish Erasmus students in literature (Mutlu et.al. 2010; Önder and Balci 2010; Aydin 2012; Sari 2014, ESI Rapor 2014), there is no other study focusing on global citizenship levels in terms of various variables. Despite indirect touch, this study also aims to present a contribution to the EU membership process of Turkey.

To serve the aims mentioned; following hypotheses will be tested:

H1: Global citizenship levels of Polish university students who are citizens of an EU member are higher than Turkish Erasmus students.

H2: Erasmus makes a positive contribution to global citizenship levels of Turkish students.

Last but not least, the study covers only Polish students from Europe and Turkish Erasmus students studying in three cities in Poland. Moreover, only survey method could be carried out and pre testpost test or interview techniques couldn't be employed due to limited time in Poland.

\section{Method}

\subsection{Research Model}

In this study, survey was used as primary research method and data were collected through a comprehensive survey instrument including global citizenship scale and personal information form. The study has also benefited from academic literature review, public opinion surveys and reports

\subsection{Study Group: Why Poland?}

Turkey is not an EU member but it has been involved in Erasmus programme since the membership negotiations started in 2004. Turkish students who have experienced Erasmus are assumed that they have taken a step towards global citizenship because study abroad experience is an important experience to have global knowledge, global competence and global action abilities as noted earlier. Given the percentage of study abroad of Turkish young people (15-35 ages) is 3\% (European Commission 2011a), the value of the programme for Turkish students' global awareness is better 
understood. 15.060 students from Turkey were sent to universities in Europe within 2013-2014 academic year through Erasmus programme. According to the statistics, Poland seems to be the most popular country for Turkish students (European Commission 2014a). About 2700 preferred to study in Poland in 2012-2013 academic year (European Commission Press Release 2014). Turkey also ranks first among Erasmus students who preferred Poland in 2013-2014 academic year (European Commission 2014a). In other words, Turkish students favor Poland because; firstly, it doesn't require paper works as others do; secondly, availability of English programs; thirdly, moderate cost of living (ESI Report 2014).

Polish people's attitude towards the EU needs also to be mentioned to understand their mind maps. Polish people have the second highest rank (62\%) on being familiar with EU citizenship. That means Polish people can be accepted to have a certain level of supra-national conscious. Additionally, Polish people take the lead among EU countries (85\%) in terms of being aware of EU rights and its citizenship features (European Commission, 2013a). Polish young (15-24 years old), in that vein, represents the most conscious group (73\%) among EU members. It should also be added that $67 \%$ of Polish in 2013 and 77\% of those in 2014 say they feel European (European Commission 2014b). Given the statistics of EU commission Standard Eurobarometer, Polish people look more satisfied with EU democracy than any other member country (66\%) (European Commission 2013b).

In brief, Poland is the country which combines two important factors that serve best for our study aims: a young generation raised in the EU and the highest number of Turkish Erasmus students. For the very reasons, Warsaw, the capital and also the biggest city, Krakow, one of the biggest and most touristic cities, and Rzesow in which local motives are reflected are chosen to carry out global citizenship scale (It should be remembered that the study could be carried out in the universities that gave consent). The biggest university of Poland, University of Warsaw in Warsaw (also having the most Erasmus students), Tischner European University in Krakow, University of Information Technology and Management in Rzesow are the universities where data collection was carried out. The study group of this research includes 353 Polish university students and 201 Turkish Erasmus students in these universities. Some demographic data are listed below:

- $34 \%$ of Turkish Erasmus students are female and $65.3 \%$ of them are male while $45.9 \%$ of Polish university students are female and $54.1 \%$ of them are male.

- The biggest participation for Turkish Erasmus students comes from 20-22 ages (55.2\%) while the least participation comes from 18-19 ages (7.8\%). Polish university students in 20-22 ages group has the biggest share while those in $23+$ ages group has the lowest share $(13 \%)$.

\subsection{Data Collection Instruments}

In this study, 'personal information form' which includes variables considered to have effect on global citizenship levels, and 'global citizenship scale' developed by Morais and Ogden (2011) to measure Turkish Erasmus students and Polish university students were employed for data collection. The scale was structured as 5 point Likert scale: strongly disagree (1), disagree (2), neutral (3), agree (4), strongly agree (5). The original form of the global citizenship scale is composed of 30 items and 3 dimensions. These dimensions are; social responsibility, global competence and global civic engagement.

The Turkish version of the scale for Turkish students was adapted by Akın, A., Sarıçam, H., Akın, Ü., Yıldız, B., Demir, T., \& Kaya, M. (2014). According to the confirmatory factor analysis carried out for structure validity, it was found that the scale with 30 items and 3 dimensions fit to data $\left(x^{2}=562.22\right.$, $\mathrm{sd}=395, \mathrm{RMSEA}=.038, \mathrm{NFI}=.90, \mathrm{CFI}=.90, \mathrm{IFI}=.91, \mathrm{SRMR}=.066$ ). Factor loadings of the scale were ranked between .10 and .88 . Internal consistency reliability coefficients of the scale were found .60 for social responsibility, .69 for global competence and .89 for global civic engagement dimension.

Global citizenship scale was translated into Polish for Polish university students. Then, explanatory factor analysis was done for the structure validity of the Polish scale. KMO (Kaiser-Meyer-Olkin) and Barlett tests were done to determine if collected data were suitable for factor analysis. According to the analysis KMO value was found .910 which shows the sample's size. Results of Barlett's test were 
found significant $(\chi 2=4530.187, \mathrm{df}=435, \mathrm{p}<000)$. This proves that there is a high correlation between variables and data set.

Varimax rotation technique was used to see if the scale was separated into unrelated factors and factor loadings were analyzed because it helps to load a smaller number of variables highly onto each factor resulting in more interpretable clusters of factors. Also, it is a good general approach that simplifies the interpretation of factors (Field 2009). Stevens (2002) recommends that for a sample size of 50 a loading of 0.722 can be considered significant, for 100 the loading should be greater than 0.512 , for 200 it should be greater than 0.364 , for 300 it should be greater than 0.298 , for 600 it should be greater than 0.21 , and for 1000 it should be greater than 0.162 (Stevens 2002). For this study, this means that items having less than .298 factor loadings can be dropped from the scale. As there is no item having less than .298 factor loading, not any item was dropped in this study.

The global citizenship scale has a structure of 3 factors which explains $42.511 \%$ of the total variance. It is suggested for data over 300 that factor loadings should be over 0.298 (Stevens 2002). Minimum factor loading of items is 0.31 . Factor loadings of the first dimension- social responsibility- range from 0.39 to 0.73 . The number of items in social responsibility dimension is 6 . Factor loadings of the second dimension- global competence- range from 0.38 to 0.63 . The number of items in of global competence is 9. Factor loadings of the third dimension- global civic engagement- range from 0.31 to 0.80. The number of items in global civic engagement is 15. All in all, it is seen that both Polish and Turkish versions of the scale are compatible with the original form of it.

According to the analysis results of the reliability, Cronbach-Alpha internal consistency coefficients are .614 for Social Responsibility, .722 for Global Competence and .920 for Global Civic Engagement dimension. Cronbach-Alpha Internal Consistency Coefficient is .878 for the total of the scale. These values show that the scale is reliable.

\subsection{Data Analysis}

Collected data was analyzed using Statistical Package for the Social Sciences (SPSS) program. To be able to determine methods to be used, data was checked initially if it showed a normal distribution. To this end, Kolmogorov-Smirnov test was used because it compares the scores in the sample to a normally distributed set of scores with the same mean and standard deviation. If the test is nonsignificant $(p>.05)$ it means that the distribution of the sample is not significantly different from a normal distribution. If, however, the test is significant $(\mathrm{p}<.05)$ then the distribution in question is significantly different from a normal distribution (Field 2009). Test of normality results for both Polish university students and Turkish Erasmus students showed a significance level over than .05 , which proved a normal distribution.

Score intervals for answers of the 5 point Likert scale were interpreted as in the Table 2.

Table 2. Score intervals and their interpretation

\begin{tabular}{|l|l|l|}
\hline Score Intervals & Levels & Explanation \\
\hline $1.00-1.80$ & Strongly Disagree & Very inadequate \\
\hline $1.81-2.60$ & Disagree & Inadequate \\
\hline $2.61-3.40$ & Neutral & Average \\
\hline $3.41-4.20$ & Agree & Satisfactory \\
\hline $4.21-5.00$ & Strongly Agree & Very satisfactory \\
\hline
\end{tabular}




\section{Results}

Table 3. Global Citizenship Levels of Turkish Erasmus Students and Polish University Students

\begin{tabular}{|c|c|c|c|c|c|c|}
\hline $\begin{array}{c}\text { Global Citizenship Scale } \\
\text { Dimensions }\end{array}$ & \multicolumn{3}{|c|}{ Turkish Erasmus Students } & \multicolumn{3}{c|}{ Polish University Students } \\
\cline { 2 - 7 } & $\mathbf{N}$ & $\overline{\mathrm{X}}$ & $\mathbf{S}$ & $\mathrm{N}$ & $\overline{\mathrm{X}}$ & $\mathrm{S}$ \\
\hline Social Responsibility & 201 & 3.72 & .695 & 353 & 3.59 & .690 \\
\hline Global Competence & 201 & 3.50 & .502 & 353 & 3.29 & .575 \\
\hline Global Civic Engagement & 201 & 3.10 & .606 & 353 & 2.50 & .754 \\
\hline TOTAL & 201 & 3.34 & .398 & 353 & 2.95 & .484 \\
\hline
\end{tabular}

Table 3. shows that both Turkish Erasmus students and Polish university students have an average level of global citizenship score from the overall of the scale. However, the overall score of Turkish Erasmus students $(\bar{X}=3.34)$ is higher than that of Polish university students $(\bar{X}=2.95)$. It can be deduced from this result that Turkish Erasmus students' level of global citizenship is higher than Polish university students. As for social responsibility dimension, both groups have an average score while Turkish Erasmus students have a higher social responsibility score $(\bar{X}=3.74)$ than Polish university students' score of social responsibility dimension $(\bar{X}=3.59)$. Therefore, there is a slight difference in terms of the wish to take social responsibility in favor of Turkish Erasmus students. It is also seen that the global competence scores of both groups are lower than social responsibility dimension. This means that both Turkish Erasmus students and Polish university students have enough faith in taking responsibility but they don't have enough global competence to be able to discharge these responsibilities. On the other hand, global civic engagement is the dimension from which both Turkish Erasmus students and Polish university students get the lowest score among other dimensions. Turkish Erasmus students have an average score $(\bar{X}=3.10)$ while Polish university students have an inadequate score $(\bar{X}=2,50)$ from global civic engagement dimension. In this respect, it should be understood that Turkish Erasmus students and Polish university students don't have a strong faith in global civic engagement for solving global problems. When compared to Polish university students, Turkish Erasmus students have a better tendency to show global civic engagement behaviors.

Table 4. Descriptive Analysis of Turkish Erasmus Students' Answers to Social Responsibility Dimension

\begin{tabular}{|c|c|c|c|c|c|c|c|c|c|c|c|c|}
\hline & \multicolumn{2}{|c|}{ 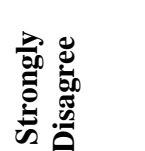 } & \multicolumn{2}{|c|}{ 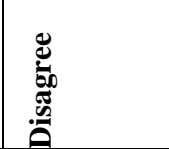 } & \multicolumn{2}{|l|}{ 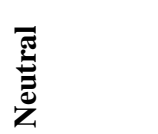 } & \multicolumn{2}{|l|}{ 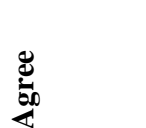 } & \multicolumn{2}{|c|}{$\frac{2}{00}$} & \multirow[t]{2}{*}{$\bar{X}$} & \multirow[t]{2}{*}{$S$} \\
\hline & $\mathrm{f}$ & $\%$ & $\mathrm{f}$ & $\%$ & $\mathrm{f}$ & $\%$ & $\mathrm{f}$ & $\%$ & $\mathrm{~F}$ & $\%$ & & \\
\hline $\begin{array}{l}1 . \text { I think that most people } \\
\text { around the world get what they } \\
\text { are entitled to have. }\end{array}$ & 62 & 30.8 & 79 & 39.3 & 30 & 14.9 & 21 & 10.4 & 9 & 4.5 & 3.81 & 1.11 \\
\hline $\begin{array}{l}\text { 2. It is OK if some people in this } \\
\text { world have more opportunities } \\
\text { than others.. }\end{array}$ & 33 & 16.4 & 59 & 29.4 & 33 & 16.4 & 67 & 33.3 & 9 & 4.5 & 3.19 & 1.19 \\
\hline $\begin{array}{l}\text { 3. I think that people around the } \\
\text { world get the rewards and } \\
\text { punishments they deserve. }\end{array}$ & 59 & 29.4 & 83 & 41.3 & 37 & 18.4 & 19 & 9.5 & 3 & 1.5 & 3.87 & .98 \\
\hline $\begin{array}{l}\text { 4. In times of scarcity, it is } \\
\text { sometimes necessary to use force } \\
\text { against others to get what you } \\
\text { need. }\end{array}$ & 55 & 27.4 & 64 & 31.8 & 46 & 22.9 & 30 & 14.9 & 6 & 3 & 3.65 & 1.12 \\
\hline $\begin{array}{l}\text { 5. The world is generally a fair } \\
\text { place. }\end{array}$ & 95 & 47.3 & 57 & 28.4 & 25 & 12.4 & 24 & 11.9 & - & - & 4.10 & 1.03 \\
\hline $\begin{array}{l}\text { 6. I feel that many people around } \\
\text { the world are poor because they } \\
\text { do not work hard enough. }\end{array}$ & 66 & 32.8 & 60 & 29.9 & 30 & 14.9 & 33 & 16.4 & 12 & 6 & 3.67 & 1,25 \\
\hline
\end{tabular}


It is seen in Table 4. that Turkish Erasmus students have answered items of social responsibility dimension of global citizenship with 'average' and 'satisfactory' scores.

Table 5. Descriptive Analysis of Turkish Erasmus Students' Answers to Global Competence Dimension

\begin{tabular}{|c|c|c|c|c|c|c|c|c|c|c|c|c|}
\hline & \multicolumn{2}{|c|}{ 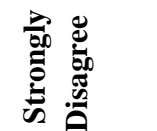 } & \multicolumn{2}{|l|}{ 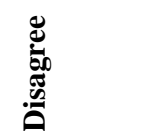 } & \multicolumn{2}{|l|}{$\underset{\bar{E}}{\bar{Z}}$} & \multicolumn{2}{|l|}{$\underset{\square}{\square}$} & \multicolumn{2}{|c|}{ 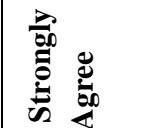 } & \multirow[t]{2}{*}{$\bar{X}$} & \multirow[t]{2}{*}{$S$} \\
\hline & $\mathrm{f}$ & $\%$ & $\mathrm{f}$ & $\%$ & $\mathrm{f}$ & $\%$ & $\mathrm{f}$ & $\%$ & $\mathrm{~F}$ & $\%$ & & \\
\hline $\begin{array}{l}\text { 7. I know how to develop a plan to } \\
\text { help mitigate a global } \\
\text { environmental or social problem. }\end{array}$ & 8 & 4 & 18 & 9 & 97 & 48.3 & 70 & 34.8 & 8 & 4 & 3.25 & .83 \\
\hline $\begin{array}{l}\text { 8. I know several ways in which I } \\
\text { can make a difference on some of } \\
\text { this world's most worrisome } \\
\text { problems. }\end{array}$ & 10 & 5 & 23 & 11.4 & 73 & 36.3 & 85 & 42.3 & 10 & 5 & 3.30 & .91 \\
\hline $\begin{array}{l}\text { 9. I am able to get other people to } \\
\text { care about global problems that } \\
\text { concern me }\end{array}$ & 4 & 2 & 22 & 10.9 & 67 & 33.3 & 96 & 47.8 & 12 & 6 & 3.44 & .84 \\
\hline $\begin{array}{l}\text { 10. I unconsciously adapt my } \\
\text { behavior and mannerisms when I } \\
\text { am interacting with people of other } \\
\text { cultures. }\end{array}$ & 16 & 8 & 35 & 17.4 & 47 & 23.4 & 83 & 41.3 & 20 & 10 & 3.27 & 1.10 \\
\hline $\begin{array}{l}\text { 11. I often adapt my communication } \\
\text { style to other people's cultural } \\
\text { background. }\end{array}$ & 6 & 3 & 38 & 18.9 & 28 & 13.9 & 98 & 48.8 & 31 & 15.4 & 3.54 & 1.05 \\
\hline $\begin{array}{l}\text { 12. I am able to communicate in } \\
\text { different ways with people from } \\
\text { different cultures. }\end{array}$ & 1 & 0.5 & 7 & 3.5 & 16 & 8 & 123 & 61.2 & 54 & 26.9 & 4.10 & .72 \\
\hline $\begin{array}{l}\text { 13. I am informed of current issues } \\
\text { that impact international relations. }\end{array}$ & 3 & 1.5 & 16 & 8 & 38 & 18.9 & 101 & 50.2 & 43 & 21.4 & 3.82 & .90 \\
\hline $\begin{array}{l}\text { 14. I feel comfortable expressing } \\
\text { my views regarding a pressing } \\
\text { global problem in front of a group } \\
\text { of people }\end{array}$ & 6 & 3 & 23 & 11.4 & 53 & 26.4 & 91 & 45.3 & 28 & 13.9 & 3.55 & .96 \\
\hline $\begin{array}{l}\text { 15. I am able to write an opinion } \\
\text { letter to a local media source } \\
\text { expressing my concerns over global } \\
\text { inequities and issues }\end{array}$ & 13 & 6.5 & 42 & 20.9 & 55 & 27.4 & 70 & 34.8 & 21 & 10.4 & 3.21 & 1.09 \\
\hline
\end{tabular}

Table 5. shows that Turkish Erasmus students have answered items of global competence dimension of global citizenship with 'average' and 'satisfactory' scores. As noted earlier, the overall score of global competence dimension is lower than that of social responsibility dimension. The items with lowest scores reveal the fact that Turkish Erasmus students feel themselves inadequate and don't have skills to act globally especially in solving global problems. The highest score of this dimension supports that these students are selected ones for Erasmus programme by taking their academic and language abilities into consideration. 
Table 6. Descriptive Analysis of Turkish Erasmus Students' Answers to Global Civic Engagement Dimension

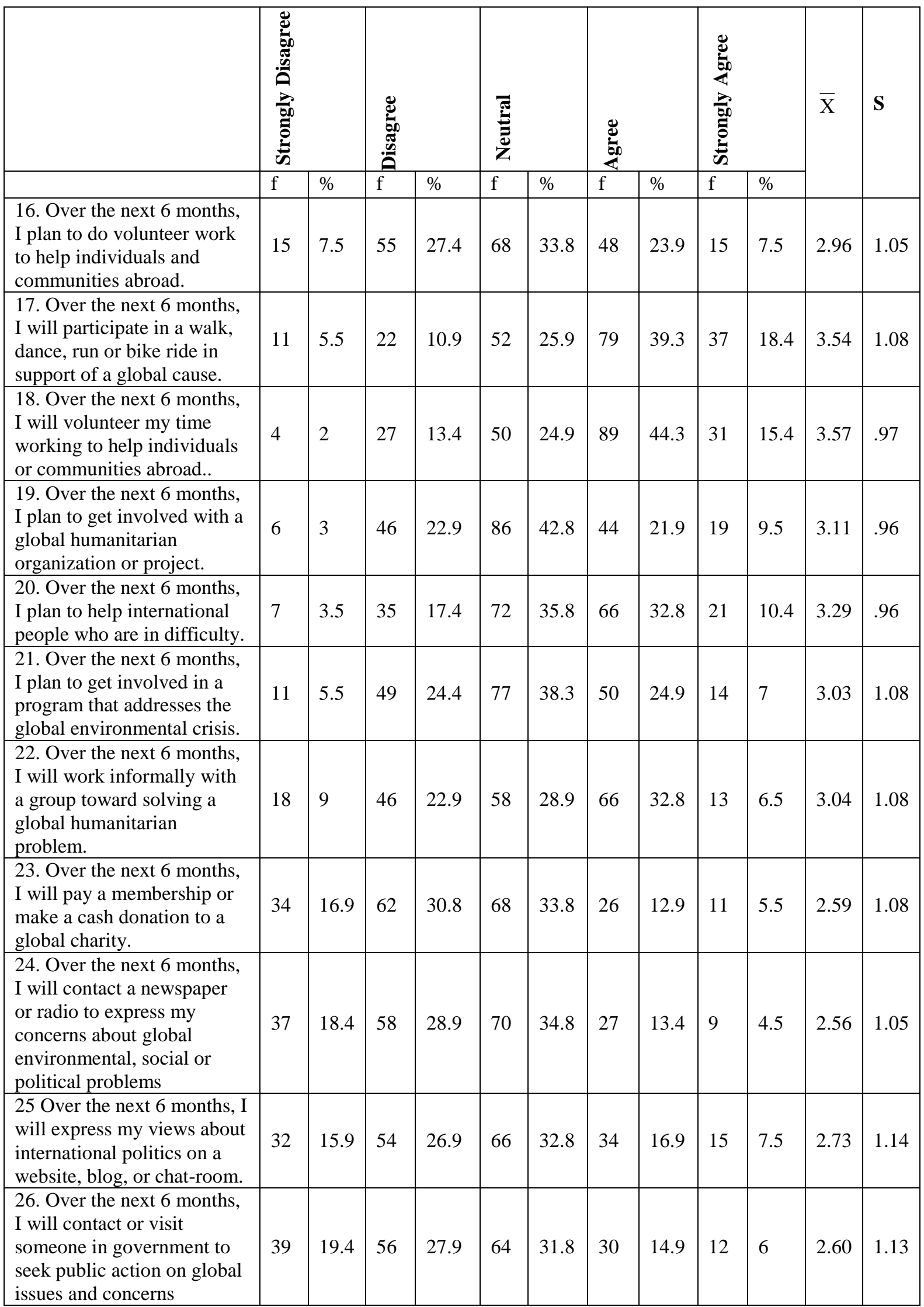




\begin{tabular}{|l|l|l|l|l|l|l|l|l|l|l|l|l|}
\hline $\begin{array}{l}\text { 27. Over the next } 6 \text { months, } \\
\text { I will participate in a } \\
\text { campus forum, live music or } \\
\text { theatre performance or other } \\
\text { event where young people } \\
\text { express their views about } \\
\text { global problems. }\end{array}$ & 18 & 9 & 43 & 21.4 & 59 & 29.4 & 63 & 31.3 & 18 & 9 & 3.09 & 1.11 \\
\hline $\begin{array}{l}\text { 28. If at all possible, I will } \\
\text { always buy fair-trade or } \\
\text { locally grown products and } \\
\text { brands. }\end{array}$ & 5 & 2.5 & 24 & 11.9 & 34 & 16.9 & 84 & 41.8 & 54 & 26.9 & 3.78 & 1.04 \\
\hline $\begin{array}{l}\text { 29. I will deliberately buy } \\
\text { brands and products that are } \\
\text { known to be good stewards } \\
\text { of marginalized people and } \\
\text { places. }\end{array}$ & 37 & 18.4 & 50 & 24.9 & 50 & 24.9 & 42 & 20.9 & 22 & 10.9 & 2.81 & 1.26 \\
\hline $\begin{array}{l}\text { 30. I will boycott brands or } \\
\text { products that are known to } \\
\text { harm marginalized global } \\
\text { people and places }\end{array}$ & 7 & 3.5 & 23 & 11.4 & 44 & 21.9 & 66 & 32.8 & 61 & 30.3 & 3.75 & 1.11 \\
\hline
\end{tabular}

Turkish Erasmus students have answered items of global civic engagement dimension of global citizenship with 'average' and 'inadequate' scores as seen in Table 6. The lowest scores of this dimension suggest that Turkish Erasmus students don't have faith in efficient ways of solving global problems such as media, politics and financial support. Also, the highest scores of the dimension can be interpreted in a way that students at least are aware of the power of being customer in solving some global problems.

Table 7. Descriptive Analysis of Polish University Students' Answers to Social Responsibility Dimension

\begin{tabular}{|c|c|c|c|c|c|c|c|c|c|c|c|c|}
\hline & \multicolumn{2}{|l|}{ 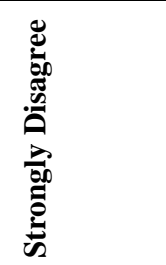 } & \multicolumn{2}{|l|}{ 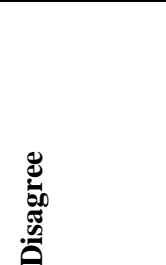 } & \multicolumn{2}{|l|}{ 馬 } & \multicolumn{2}{|l|}{ 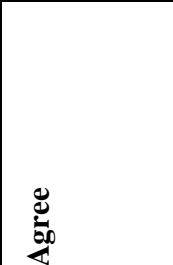 } & \multicolumn{2}{|l|}{ 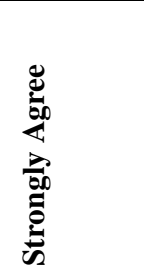 } & \multirow[t]{2}{*}{$\bar{X}$} & \multirow[t]{2}{*}{$\mathrm{S}$} \\
\hline & $\mathrm{f}$ & $\%$ & $\mathrm{f}$ & $\%$ & $\mathrm{f}$ & $\%$ & $\mathrm{f}$ & $\%$ & $\mathrm{f}$ & $\%$ & & \\
\hline $\begin{array}{l}\text { 1. I think that most people around } \\
\text { the world get what they are } \\
\text { entitled to have. }\end{array}$ & 63 & 17.8 & 151 & 42.8 & 71 & 20.1 & 55 & 15.6 & 13 & 3.7 & 3.55 & 1.06 \\
\hline $\begin{array}{l}\text { 2. It is OK if some people in this } \\
\text { world have more opportunities } \\
\text { than others.. }\end{array}$ & 88 & 24.9 & 125 & 35.4 & 52 & 14.7 & 65 & 18.4 & 23 & 6.5 & 3.53 & 1.22 \\
\hline $\begin{array}{l}\text { 3. I think that people around the } \\
\text { world get the rewards and } \\
\text { punishments they deserve. }\end{array}$ & 85 & 24.1 & 118 & 33.4 & 56 & 15.9 & 62 & 17.6 & 32 & 9.1 & 3.45 & 1.27 \\
\hline $\begin{array}{l}\text { 4. In times of scarcity, it is } \\
\text { sometimes necessary to use force } \\
\text { against others to get what you } \\
\text { need. }\end{array}$ & 132 & 37.4 & 104 & 29.5 & 55 & 15.6 & 44 & 12.5 & 18 & 5.1 & 3.81 & 1.20 \\
\hline $\begin{array}{l}\text { 5. The world is generally a fair } \\
\text { place. }\end{array}$ & 120 & 34 & 141 & 39.9 & 51 & 14.4 & 30 & 8.5 & 11 & 3.1 & 3.93 & 1.05 \\
\hline $\begin{array}{l}\text { 6. I feel that many people around } \\
\text { the world are poor because they } \\
\text { do not work hard enough. }\end{array}$ & 58 & 16.4 & 126 & 35.7 & 58 & 16.4 & 81 & 22.9 & 30 & 8.5 & 3.28 & 1.22 \\
\hline
\end{tabular}

Table 7. shows that Polish university students have answered items of social responsibility dimension of global citizenship with 'average' and 'satisfactory' scores like Turkish students. However, the overall score of Polish university students from this dimension is lower than Turkish Erasmus students. The lowest score (3.28) of the dimension belongs to the item 'I feel that many people around 
the world are poor because they do not work hard enough.' That of Turkish Erasmus students (3.67) is higher than Polish university students, which means that Polish students see a higher correlation between hard working and well-being. The highest score that Polish university students get from this dimension belongs to the same item as Turkish Erasmus students. Findings of these dimensions can be summarized that Polish university students have an average level of faith in taking social responsibility, though not as much as Turkish students.

Table 8. Descriptive Analysis of Polish University Students’ Answers to Global Competence Dimension

\begin{tabular}{|c|c|c|c|c|c|c|c|c|c|c|c|c|}
\hline & \multicolumn{2}{|c|}{ 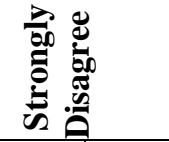 } & \multicolumn{2}{|c|}{ 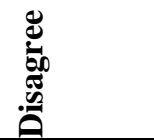 } & \multicolumn{2}{|l|}{ 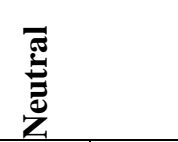 } & \multicolumn{2}{|l|}{ 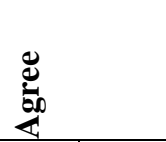 } & \multicolumn{2}{|c|}{ 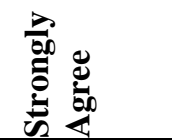 } & \multirow[t]{2}{*}{$\bar{X}$} & \multirow[t]{2}{*}{ S } \\
\hline & $\mathrm{f}$ & $\%$ & $\mathrm{f}$ & $\%$ & $\mathrm{f}$ & $\%$ & $\mathrm{f}$ & $\%$ & $\mathrm{f}$ & $\%$ & & \\
\hline $\begin{array}{l}\text { 7. I know how to develop a } \\
\text { plan to help mitigate a global } \\
\text { environmental or social } \\
\text { problem. }\end{array}$ & 36 & 10.2 & 83 & 23.5 & 141 & 39.9 & 80 & 22.7 & 13 & 3.7 & 2.86 & 1.00 \\
\hline $\begin{array}{l}\text { 8. I know several ways in } \\
\text { which I can make a difference } \\
\text { on some of this world's most } \\
\text { worrisome problems. }\end{array}$ & 28 & 7.9 & 82 & 23.2 & 123 & 34.8 & 97 & 27.5 & 23 & 6.5 & 3.01 & 1.04 \\
\hline $\begin{array}{l}\text { 9. I am able to get other } \\
\text { people to care about global } \\
\text { problems that concern me }\end{array}$ & 25 & 7.1 & 82 & 23.2 & 124 & 35.1 & 104 & 29.5 & 18 & 5.1 & 3.02 & 3.02 \\
\hline $\begin{array}{l}\text { 10. I unconsciously adapt my } \\
\text { behavior and mannerisms } \\
\text { when I am interacting with } \\
\text { people of other cultures. }\end{array}$ & 12 & 3.4 & 46 & 13 & 87 & 24.6 & 163 & 46.2 & 45 & 12.7 & 3.51 & 1.00 \\
\hline $\begin{array}{l}\text { 11. I often adapt my } \\
\text { communication style to other } \\
\text { people's cultural background. }\end{array}$ & 12 & 3.4 & 58 & 16.4 & 58 & 16.4 & 177 & 50.1 & 48 & 13.6 & 3.54 & 1.02 \\
\hline $\begin{array}{l}\text { 12. I am able to communicate } \\
\text { in different ways with people } \\
\text { from different cultures. }\end{array}$ & 9 & 2.5 & 22 & 6.2 & 75 & 21.2 & 175 & 49.6 & 72 & 20.4 & 3.79 & .92 \\
\hline $\begin{array}{l}\text { 13. I am informed of current } \\
\text { issues that impact } \\
\text { international relations. }\end{array}$ & 15 & 4.2 & 52 & 14.7 & 77 & 21.8 & 159 & 45 & 50 & 14.2 & 3.50 & 1.04 \\
\hline $\begin{array}{l}\text { 14. I feel comfortable } \\
\text { expressing my views } \\
\text { regarding a pressing global } \\
\text { problem in front of a group of } \\
\text { people }\end{array}$ & 19 & 5.4 & 62 & 17.6 & 101 & 28.6 & 124 & 35.1 & 47 & 13.3 & 3.33 & 1.07 \\
\hline $\begin{array}{l}\text { 15. I am able to write an } \\
\text { opinion letter to a local media } \\
\text { source expressing my } \\
\text { concerns over global } \\
\text { inequities and issues }\end{array}$ & 28 & 7.9 & 63 & 17.8 & 135 & 38.2 & 97 & 27.5 & 30 & 8.5 & 3.10 & 1.04 \\
\hline
\end{tabular}

Table 8. shows that Polish university students have answered items of global competence dimension of global citizenship with 'average' and 'satisfactory' scores. Yet, Polish university students' scores of most items in this dimension are lower than that of Turkish Erasmus students. On the other hand, Polish university students have a lower overall score from this dimension than social responsibility dimension just like Turkish Erasmus students. When looked at the lowest items, there is a similarity between Turkish and Polish students except one item from which Turks have a higher score. This finding may reveal that Polish students have a lesser faith in individual and social persuasive behaviours aiming to care global problems than Turkish students. It is the same item that Polish and 
Turkish students have the highest score: 'I am able to communicate in different ways with people from different cultures.' It should be, however, noted Turkish students have a higher score (4.10) from this item than Polish students (3.79).

Table 9. Descriptive Analysis of Polish University Students' Answers to Global Civic Engagement Dimension

\begin{tabular}{|c|c|c|c|c|c|c|c|c|c|c|c|c|}
\hline & \multicolumn{2}{|c|}{ 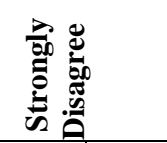 } & \multicolumn{2}{|c|}{ 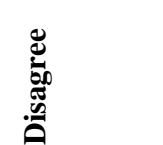 } & \multicolumn{2}{|l|}{ 焉 } & \multicolumn{2}{|l|}{ 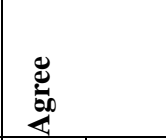 } & \multicolumn{2}{|c|}{ 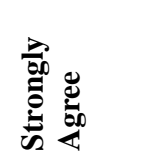 } & \multirow[t]{2}{*}{$\bar{X}$} & \multirow[t]{2}{*}{$S$} \\
\hline & $\mathrm{f}$ & $\%$ & $\mathrm{f}$ & $\%$ & $\mathrm{f}$ & $\%$ & $\mathrm{f}$ & $\%$ & $\mathrm{f}$ & $\%$ & & \\
\hline $\begin{array}{l}\text { 16. Over the next } 6 \text { months, I plan } \\
\text { to do volunteer work to help } \\
\text { individuals and communities } \\
\text { abroad. }\end{array}$ & 103 & 29.2 & 103 & 29.2 & 95 & 26.9 & 42 & 11.9 & 10 & 2.8 & 2.30 & 1.09 \\
\hline $\begin{array}{l}\text { 17. Over the next } 6 \text { months, I will } \\
\text { participate in a walk, dance, run or } \\
\text { bike ride in support of a global } \\
\text { cause. }\end{array}$ & 79 & 22.4 & 102 & 28.9 & 99 & 28 & 56 & 15.9 & 17 & 4.8 & 2.51 & 1.14 \\
\hline $\begin{array}{l}\text { 18. Over the next } 6 \text { months, I will } \\
\text { volunteer my time working to help } \\
\text { individuals or communities } \\
\text { abroad.. }\end{array}$ & 84 & 23.8 & 104 & 29.5 & 101 & 28.6 & 51 & 14.4 & 13 & 3.7 & 2.44 & 1.11 \\
\hline $\begin{array}{l}\text { 19. Over the next } 6 \text { months, I plan } \\
\text { to get involved with a global } \\
\text { humanitarian organization or } \\
\text { project. }\end{array}$ & 92 & 26.1 & 104 & 29.5 & 110 & 31.2 & 36 & 10.2 & 11 & 3.1 & 2.34 & 1.06 \\
\hline $\begin{array}{l}\text { 20. Over the next } 6 \text { months, I plan } \\
\text { to help international people who } \\
\text { are in difficulty. }\end{array}$ & 80 & 22.7 & 100 & 28.3 & 114 & 32.3 & 49 & 13.9 & 10 & 2.8 & 2.45 & 1.07 \\
\hline $\begin{array}{l}21 . \text { Over the next } 6 \text { months, I plan } \\
\text { to get involved in a program that } \\
\text { addresses the global environmental } \\
\text { crisis. }\end{array}$ & 79 & 22.4 & 109 & 30.9 & 125 & 35.4 & 37 & 10.5 & 3 & .8 & 2.36 & .97 \\
\hline $\begin{array}{l}\text { 22. Over the next } 6 \text { months, I will } \\
\text { work informally with a group } \\
\text { toward solving a global } \\
\text { humanitarian problem. }\end{array}$ & 86 & 24.4 & 107 & 30.3 & 117 & 33.1 & 36 & 10.2 & 7 & 2 & 2.35 & 1.02 \\
\hline $\begin{array}{l}\text { 23. Over the next } 6 \text { months, I will } \\
\text { pay a membership or make a cash } \\
\text { donation to a global charity. }\end{array}$ & 85 & 24.1 & 82 & 23.2 & 121 & 34.3 & 53 & 15 & 12 & 3.4 & 2.50 & 1.11 \\
\hline $\begin{array}{l}\text { 24. Over the next } 6 \text { months, I will } \\
\text { contact a newspaper or radio to } \\
\text { express my concerns about global } \\
\text { environmental, social or political } \\
\text { problems }\end{array}$ & 118 & 33.4 & 119 & 33.7 & 84 & 23.8 & 23 & 6.5 & 9 & 2.5 & 2.11 & 1.02 \\
\hline $\begin{array}{l}25 \text { Over the next } 6 \text { months, I will } \\
\text { express my views about } \\
\text { international politics on a website, } \\
\text { blog, or chat-room. }\end{array}$ & 84 & 23.8 & 90 & 25.5 & 85 & 24.1 & 70 & 19.8 & 24 & 6.8 & 2.60 & 1.23 \\
\hline $\begin{array}{l}\text { 26. Over the next } 6 \text { months, I will } \\
\text { contact or visit someone in } \\
\text { government to seek public action } \\
\text { on global issues and concerns }\end{array}$ & 102 & 28.9 & 113 & 32 & 104 & 29.5 & 28 & 7.9 & 6 & 1.7 & 2.21 & 1.00 \\
\hline $\begin{array}{l}\text { 27. Over the next } 6 \text { months, I will } \\
\text { participate in a campus forum, live } \\
\text { music or theatre performance or } \\
\text { other event where young people } \\
\text { express their views about global } \\
\text { problems. }\end{array}$ & 66 & 18.7 & 91 & 25.8 & 105 & 29.7 & 70 & 19.8 & 21 & 5.9 & 2.68 & 1.16 \\
\hline
\end{tabular}




\begin{tabular}{|l|l|l|l|l|l|l|l|l|l|l|l|l|}
\hline $\begin{array}{l}\text { 28. If at all possible, I will always } \\
\text { buy fair-trade or locally grown } \\
\text { products and brands. }\end{array}$ & 41 & 11.6 & 77 & 21.8 & 128 & 36.3 & 87 & 24.6 & 20 & 5.7 & 2.90 & 1.07 \\
\hline $\begin{array}{l}\text { 29. I will deliberately buy brands } \\
\text { and products that are known to be } \\
\text { good stewards of marginalized } \\
\text { people and places. }\end{array}$ & 53 & 15 & 70 & 19.8 & 112 & 31.7 & 105 & 29.7 & 13 & 3.7 & 2.87 & 1.10 \\
\hline $\begin{array}{l}\text { 30. I will boycott brands or } \\
\text { products that are known to harm } \\
\text { marginalized global people and } \\
\text { places }\end{array}$ & 64 & 18.1 & 78 & 22.1 & 106 & 30 & 76 & 21.5 & 29 & 8.2 & 2.79 & 1.20 \\
\hline
\end{tabular}

Most of the items' scores of Polish university students in global civic engagement dimension are inadequate, very few scores are average (Table 9.). It is seen from the table that Polish students show the same attitude as Turkish students towards efficient ways to solve global problems such as media, politics and financial support: They do not have enough faith in these ways.

Table 10. T-test results of Turkish Erasmus Students' View on The Relationship Between Their Education in Poland and Global Citizenship

\begin{tabular}{|c|c|c|c|c|c|c|c|}
\hline Dimensions and Global Citizenship & $\begin{array}{c}\text { Education } \\
\text { Effect }\end{array}$ & $\mathbf{N}$ & $\overline{\mathrm{X}}$ & $\mathbf{S}$ & $\mathbf{s d}$ & $\mathbf{t}$ & $\mathbf{p}$ \\
\hline \multirow{2}{*}{ Social Responsibility } & Yes & 145 & 22.37 & 4.27 & 199 & .278 & .781 \\
\cline { 2 - 7 } & No & 56 & 22.19 & 3.93 & & & \\
\hline \multirow{2}{*}{ Global Competence } & Yes & 145 & 32.05 & 4.34 & 199 & 2.734 & .007 \\
\cline { 2 - 6 } & No & 56 & 30.16 & 4.70 & & & \\
\hline Global Civic Engagement & Yes & 145 & 47.79 & 8.70 & 199 & 3.264 & .001 \\
\cline { 2 - 6 } & No & 56 & 43.23 & 9.33 & & & \\
\hline Global Citizenship & Yes & 145 & 102.24 & 12.04 & 199 & 3.644 & .000 \\
\cline { 2 - 5 } & No & 56 & 95.58 & 10.40 & & & \\
\hline
\end{tabular}

The Turkish Erasmus students were asked if the education they were having in Poland made any effect on their being global citizen. Table 10. shows that there is a significance between the Erasmus education in Poland and global competence $[\mathrm{t}(199)=3.117 ; \mathrm{p}<0.05]$, global civic engagement [t(199) $=3.264 ; \mathrm{p}<0.05]$ dimensions and total score of the global citizenship scale. This significance has been found in favour of those believing that the education they have in Poland has an (positive) effect on their global citizenship. There is no significance for social responsibility dimension [t $(199)=.278$; $\mathrm{p}>0.05]$. From these results, it can be said that Erasmus experience has an effect on global citizenship levels of Turkish Erasmus students in Poland.

Table 11. Self-assessments of The Study Group Towards Their National Citizenship Levels

\begin{tabular}{|c|c|c|c|c|c|c|}
\hline \multirow{2}{*}{$\begin{array}{c}\text { National Citizenship } \\
\text { Level }\end{array}$} & \multicolumn{2}{|c|}{ Turkish Erasmus Students } & \multicolumn{3}{|c|}{ Polish University Students } \\
\cline { 2 - 3 } & $\mathrm{f}$ & $\%$ & $\overline{\mathrm{X}}$ & $\mathrm{f}$ & $\%$ & $\overline{\mathrm{X}}$ \\
\hline Low & 16 & 8 & \multirow{3}{*}{6.83} & 8 & 2.3 & \multirow{2}{*}{7.00} \\
\hline Medium & 103 & 51.2 & 210 & 59.5 & \\
\hline High & 82 & 40.8 & & 135 & 38.2 & \\
\hline Total & 201 & 100 & & 353 & 100 & \\
\hline
\end{tabular}

The study group was asked to make a self-assessment to describe their national citizenship level. To this end, they were asked to grade themselves from 1 to 10 . For the interpretation of their grading, this criteria was used: $1-3$ points $=$ low $; 4-7$ points $=$ medium $; 8-10$ points $=$ high . Given this criteria, Turkish Erasmus students have a medium level of national citizenship (6.83) while Polish university students have a higher national citizenship score (7.00). 
Table 12. Self-assessments of The Study Group Towards Their Global Citizenship Levels

\begin{tabular}{|c|c|c|c|c|c|c|}
\hline Global Citizenship Level & \multicolumn{2}{|c|}{ Turkish Erasmus Students } & \multicolumn{3}{|c|}{ Polish University Students } \\
\cline { 2 - 3 } & $\mathrm{f}$ & $\%$ & $\overline{\mathrm{X}}$ & $\mathrm{f}$ & $\%$ & $\overline{\mathrm{X}}$ \\
\hline Low & 21 & 10.4 & \multirow{3}{*}{6.28} & 32 & 9.1 & \multirow{2}{*}{6.12} \\
\cline { 2 - 3 } \cline { 5 - 6 } & 119 & 59.2 & & 225 & 63.7 & \\
\hline Medium & 61 & 30.3 & & 96 & 27.2 & \\
\hline High & 201 & 100 & & 353 & 100 & \\
\hline Total & & &
\end{tabular}

The study group was also asked to make a self-assessment to describe their global citizenship level. It is seen that Turkish Erasmus students have a medium level of global citizenship (6.28) and Polish university students have also a medium level of global citizenship (6.12). These findings prove that Turkish Erasmus students feel slightly more global citizenship than Polish university students.

\section{Discussion}

H1: Global citizenship levels of Polish university students who are citizens of an EU member are higher than Turkish Erasmus students; False:

Total score of global citizenship scale of Turkish Erasmus students (3.34) is higher than that of Polish university students (2.95) as seen in Table 3. It means that global citizenship levels of Turkish Erasmus students in Poland are higher than that of Polish university students. Both Turkish Erasmus students and Polish university students have an average level of social responsibility; however, Turkish Erasmus students' score (3.74) is higher than Polish university students (3.59) in this dimension. From social responsibility dimension results, it can be said that Turkish Erasmus students have slightly more will than Polish university students to take responsibilities in terms of global justice and disparities; altruism and empathy, global interconnectedness and personal responsibility. As for global competence dimension, both Turkish Erasmus students and Polish university students have a lower total score than social responsibility dimension. This means both group lack enough level of self-awareness, intercultural communication and global knowledge. The biggest difference between Turkish Erasmus students and Polish university students are seen in global civic engagement dimension. In this dimension, Turkish Erasmus students have an average score (3.10) while Polish university students have an inadequate score (2.50). According to these result; both Turkish Erasmus students and Polish university students do not have a strong faith in involvement in civic organizations, political voice and global civic activism behaviours requiring participation to solve global problems; and Turkish Erasmus students have a more tendency to show these behaviours compared to Polish university students.

Average national citizenship score of Turkish Erasmus students (6.83) is lower than that of Polish university students (7.00) as shown in Table 11. Given national citizenship self-assessment results, global citizenship self-assessment results and global citizenship scale results seem more meaningful as Polish students seem more national than Turkish while Turkish students seem more global than Polish. This finding shows parallelism with the study of Mutlu et.al. (2010) in which they compare Turkish Erasmus students with other Erasmus students of EU members. Mutlu et.al. (2010) find that Turkish Erasmus students (52\%) feel more world citizen than other Erasmus students from EU member countries $(42.1 \%)$.

It is necessary to understand the zeitgeist (2015) and historical background to grasp these findings. The combination of 2008 European economic crisis with migration flow from Syrian war to Europe served to the raise of nationalistic movements and decline in global citizenship issues. Therefore, the rightist parties that based their policies mostly on anti-migration, nationalism and populism gained momentum throughout the Europe. At this point, governments formed by nationalist (anti global citizenship) parties may attract public to the line of anti-migration/Muslim feelings. The sign of nationalistic party's raise in Poland was seen in 2005 in which adverse effects of free trade economy started to be felt (Kania-Lundholm 2012). After communism, it was the first time in Poland when the majority government was formed by a rightist/conservative party, Law and Justice Party. For another example, it is remarkable to remember the march of 50.000 people in Warsaw, one of the biggest 
rallies in Poland of recent times, against migration to Europe. European Commission against Racism and Intolerance 2015 report indicates that there is a raise in the number of ultra-nationalists and hate speeches against Muslims in web sites in Poland since 2009. (ECRI 2015). This situation can be explained by the nationalist expression that shows up in crisis periods (Bilig, as cited in Özkırımlı 2008). Looking at 2011 and 2013 Eurobarometer surveys makes crisis periods more understandable. According to those surveys, main concerns of European people are rising prices, unemployment, the national economic situation, taxation, the financial situation of the household and health and social security issues. Though the ranking not exactly the same, the same issues concern Polish people (EU Commission 2011b, EU Commission 2013b). It should also be noted that what has been happening in Europe and in Poland cannot solely be explained by the raise of nationalism. It is more pumping nationalism which has chronic background in Poland and in Europe just like in every nation state (Özkırımlı 2008). As a matter of fact, that nationalistic ideology was used functionally to reorganize societies of post communism at national base. Poland is one of these countries. As a consequence of political vacuum of communism which had a universal claim, nationalistic reaction took the stage. Citizens of eastern bloc countries embraced nationalism as they couldn't identify themselves in Western models of globalization age (Oğurlu 2007). More deep down in Polish history, the country is full of separations, statelessness and invasions for 300 years. Therefore, strong Polish identity can be seen as a result of years of struggles to protect Polish culture, tradition and language (Oğurlu 2007). Table 13. gives opinion for roots and evolution of patriotic -nationalist- thought in Poland over centuries.

Table 13. Patriotic traditions in Polish nationalism (Kania-Lundholm, 2012)

\begin{tabular}{|c|c|c|}
\hline Patriotic Tradition & Definition of Nation & Forms of Patriotism \\
\hline $\begin{array}{c}\text { Republican: Civic (1569-1795) } \\
\text { The Polish-Lithuanian } \\
\text { Commonwealth }\end{array}$ & $\begin{array}{c}\text { Political } \\
\text { (collective freedom) }\end{array}$ & National will \\
\hline $\begin{array}{c}\text { Romantic: Cultural (1795-1918) } \\
\text { Partitions }\end{array}$ & $\begin{array}{c}\text { Ethno cultural } \\
\text { (Romantic messianism) }\end{array}$ & National idea \\
\hline $\begin{array}{c}\text { Realist: Ethnic (1918-1939) } \\
\text { The Second Republic }\end{array}$ & $\begin{array}{c}\text { Ethno-religious } \\
\text { (Polak-Katolik) }\end{array}$ & National interest \\
\hline
\end{tabular}

Remembering the low scores of Polish university students in global civic engagement dimension which mostly questions volunteer actions, it is not surprising to see in fieldworks of EU commission that European young people feel hesitant to act voluntarily. According to a fieldwork, only $25 \%$ of young people in the EU say that they have been involved in an organized voluntary activity in the past 12 months. In addition to this, only $13 \%$ of young people in the EU say that they have been involved in organizations of political, human rights or environmental issues -which can be seen as a part of global civic engagement acts-in the past 12 months (European Commission 2015a).

H2: Erasmus programme makes a positive contribution to global citizenship levels of Turkish students. True

According to Table 10. 145 Turkish students out of 201 think that the education they get in Poland influence their global citizenships. Also, those students saying 'yes' to this question have a higher global citizenship score than those saying 'no'. This finding shows similarity with studies of Braskamp et.al (2009), Schatte (2009), Perry et.al. (2013) and Samra (2007) who suggests that education abroad helps individuals' global learning and development by recognizing responsibilities beyond his/her own society and showing tendency to change his/her behaviours and decisions. The study of Sutton and Rubin (2004) supports this finding, too. They compare students having education abroad and students not having education abroad. They suggest that those having education abroad shows better skills in terms of functional knowledge, earth's geographical knowledge, cultural relativity knowledge and global interdependence knowledge. 
Engin and Sarsar (2015) who conducted the very same Morais and Ogden (2011) global citizenship scale on Turkish students studying in Turkey revealed that Turkish Erasmus students have a higher level of global citizenship. This also supports the idea that Erasmus programme makes positive contribution to global citizenship levels of Turkish students. Sari (2014) reaches similar conclusions in his thesis on Turkish and other Erasmus students. According to the tests he conducted before and after Erasmus experience; Turks becomes more interested in European issues, feels more European, realizes European values more and become more European in terms of citizenship.

EU Commission report (2011a) gives opinion of what Turkish young people think about abroad experiences. For Turkish young people, the most important benefit of abroad experience is 'the awareness of another culture' (which may be referred to the global competence skills). This finding explains why Turkish Erasmus students gets the highest score from the item 'I am able to communicate in different ways with people from different cultures.' in global competence dimension (Table 5.). In other words, Turkish young people see abroad experience as a chance to understand another culture and Erasmus seems to have given this opportunity to them. Among EU members and candidates, Turkish young people take the lead in terms of willingness to go abroad. However, Turkish young people were the most likely to say that family commitments stop them from going abroad (41\%) (European Commission 2011a). This finding may help us understand why Turkish Erasmus students get the lowest score from global civic engagement dimension (3.10) compared to social responsibility (3.70) and global competence (3.50) dimensions (Table 3.).

\section{Conclusion and Recommendations}

Given $87 \%$ of Polish participants of the study group is at the age of 18-22 years, which means that these students have got all their education during EU membership and none of them has an experience of communism era, it is clearly understood that EU membership is not on its own enough to make a young person to have a satisfactory level of global citizenship. On the other hand, Turkish Erasmus students have made use of Erasmus experience as a way to feel more global citizen. 51\% of Polish population has no even interest in going abroad despite the right of free movement (European Commission 2011a). It seems that nationalistic and anti-migration zeitgeist nourished by economic concerns wins over the EU's supra national/global citizenship target.

When thought at European scale, EU faces migration issues, Brexit (Britain's decision to exit from EU) and Greece economic crisis. That conscious of supra national citizenship have not taken place of national citizenship can be both seen in the results of the study and in the raise of rightist/nationalistic parties. Migration issues erode European values, Brexit threatens the existence of the Union and economic crisis in Greece infects European economies. Therefore, future studies should be focusing on the background of these processes. As for global citizenship subject, why citizens of EU members cannot feel somehow they belong to EU citizenship requires more studies.

Turkish Erasmus students are good example for the effect of study abroad education on creating global citizens. Although Turkey is not a European Union member, its young population (at least those prefer to go Erasmus) seems open to be a global citizen. For further studies, this global citizenship scale should be conducted on Turkish Erasmus students studying in West and Central European countries to be able to generalize results of Turkish Erasmus students in Poland to all Turkish Erasmus students. By this way, it will be then possible to compare and contrast the effect of Erasmus programme in terms of global citizenship levels. Also, the global citizenship scale should be supported qualitative interviews to analyse deeper reasons of the results.

\section{References}

[1] Akın, Ahmet., Sarıçam, H., Akın, Ü., Yıldız, B., Demir, T., \& Kaya, M. (2014). The validity and reliability of the Turkish version of the Global Citizienship Scale. Paper presented at the 3rd International Symposium on Social Studies Education, April, 28-30, Ankara, Turkey.

[2] Albrow, M. (1996).Global Age. John Wiley \& Sons, Ltd. 
[3] Alger, C. F., \& Harf, J. E. (1985). Global education: Why? For whom? About what?. The American Association of Colleges for Teacher Education for the Guidelines for International Teacher Education Project. http://files.eric.ed.gov/fulltext/ED265107.pdf. Accessed 15 May 2017

[4] Armstrong, C. (2006). Global civil society and the question of global citizenship.Voluntas: International Journal of Voluntary and Nonprofit Organizations, 17(4), 348-356.

[5] Basok, T. (2004). Post-national citizenship, social exclusion and migrants rights: Mexican seasonal workers in Canada.Citizenship studies,8(1), 47-64.

[6] Bauman, Z. (2011).Collateral damage: Social inequalities in a global age. Polity.

[7] Beck, U. (2003). Toward a new critical theory with a cosmopolitan intent.Constellations, 10(4), 453-468.

[8] Beck, U. (2005).Power in the global age: A new global political economy. Polity.

[9] Bergman, Lisa (2015). The Erasmus Program and European Identity, Master dissertation, Twente University, Twente

[10] Braskamp, L. A., Braskamp, D. C., \& Merrill, K. (2009). Assessing Progress in Global Learning and Development of Students with Education Abroad Experiences.Frontiers: The Interdisciplinary Journal of Study Abroad, 18, 101-118.

[11] Delanty, G. (2000).Citizenship in a global age. McGraw-Hill Education (UK).

[12] Dower, N. (2000). The idea of global citizenship-A sympathetic assessment. Global Society, 14(4), 553-567.

[13] Dower, N., \& Williams, J. (2003). An introduction to global citizenship. Edinburgh: Edinburgh University Press.

[14] ECRI (European Commission Against Racism and Tolerance) (2015) Report on Poland, https://www.coe.int/t/dghl/monitoring/ecri/Country-by-country/Poland/POL-CbC-V-2015-20ENG.pdf. Accessed 15 May 2017

[15] Engin, G., \& Sarsar, F. (2015). Investigation of primary school teacher candidates' global citizenship levels Sınıf öğretmeni adaylarının küresel vatandaşlık düzeylerinin incelenmesi, Journal of Human Sciences, 12(1), 150-161.

[16] ESI Arka Plan Araştırması (2014), Türk Öğrenciler, Tecrit ve Erasmus Sorunsalı, http://www.esiweb.org/pdf/Turk\%20Ogrenciler,\%20Tecrit\%20ve\%20Erasmus\%20Sorunsali\%20 (24\%20Temmuz\%202014).pdf Accessed 15 May 2017

[17] European Commission (1987) 87/327/EEC Resolution Number, lex.europa.eu/LexUriServ/LexUriServ.do?uri=CELEX:31987D0327:EN:HTML, Accessed 15 May 2017

[18] European Commission (2011a), Flash Barometer Youth On the Move, http://ec.europa.eu/public_opinion/flash/fl_319b_en.pdf . Accessed 15 May 2017

[19] European Commission (2011b). Flash Barometer, http://ec.europa.eu/public_opinion/archives/eb/eb74/eb74_cri_en.pdf . Accessed 15 May 2017

[20] European Commission (2013a), Flash Barometer 365 European Union Citizenship, http://ec.europa.eu/public_opinion/flash/fl_365_en.pdf . Accessed 15 May 2017

[21] European Commission (2013b) Standard Euro Barometer 79 Public Opinion in European Union, http://ec.europa.eu/public_opinion/archives/eb/eb79/eb79_first_en.pdf . Accessed 15 May 2017

[22] European Commission (2014a), Erasmus+ Programme Annual Report, http://ec.europa.eu/education/library/statistics/erasmus-plus-annual-report_en.pdf . Accessed 22 May 2017 
[23] European Commission (2014b). Standard Barometer, http://ec.europa.eu/public_opinion/archives/eb/eb81/eb81_publ_fr.pdf . Accessed 22 May 2017

[24] European Commission (2015a) Flash Eurometer 408 European Youth, http://ec.europa.eu/public_opinion/flash/fl_408_en.pdf . Accessed 15 May 2017

[25] European Commission (2015b), Erasmus Facts, Figures and Trends, http://ec.europa.eu/education/library/statistics/erasmus-plus-facts-figures_en.pdf Accessed 20 May 2017

[26] European Commission Press Release (2014), http://europa.eu/rapid/press-release_IP-14821_en.htm. Accessed 15 May 2017

[27] Fernández, Ó. (2005). Towards European citizenship through higher education? European Journal of Education,40(1), 60-68.

[28] Field, A. (2009).Discovering statistics using SPSS. Sage publications.

[29] Folk, R. (1993). The making of global citizenship. Global visions: Beyond the new world order, 39.

[30] Giddens, A. (2013).Europe in the global age. John Wiley \& Sons.

[31] Held, D. (2002). Violence, law, and justice in a global age. Constellations,9(1), 74-88.

[32] Hutchings, K., \& Dannreuther, R. (1999).Cosmopolitan citizenship. Macmillan Press.

[33] Kania-Lundholm, Magdalena. (2012). Re-Branding a Nation Online: Discourses on Polish Nationalism and Patriotism, Doctoral dissertation, Uppsala University, Uppsala

[34] Kant, I. (2010). Toward Perpetual Peace: A Philosophical Sketch (1795).Toward Perpetual Peace and Other Writings on Politics, Peace and History: Immanuel Kant, ed. Pauline Kleingeld (New Haven, CT: Yale University Press, 2006), 69, 19.

[35] King, R., \& Ruiz-Gelices, E. (2003). International student migration and the European 'year abroad': effects on European identity and subsequent migration behaviour. International Journal of Population Geography,9(3), 229-252.

[36] Kniep, W. M. (1986). Defining A Global Education by Its Content. Social education, 50(6), 43746

[37] Kuhn, T. (2012). Why Educational Exchange Programmes Miss Their Mark: Cross-Border Mobility, Education and European Identity. JCMS: Journal of Common Market Studies,50(6), 994-1010.

[38] Lagos, T. G. (2002). Global citizenship-towards a definition. http://citeseerx.ist.psu.edu/viewdoc/download?doi=10.1.1.540.1819\&rep=rep1\&type=pdf Accessed 15 May 2017

[39] Lang, J. S. (2013). Assessing the impact of various experiences on students' levels of global citizenship.,Master dissertation, Oregeon State University

[40] Linklater, A. (1998). Cosmopolitan citizenship.Citizenship studies,2(1), 23-41.

[41] Linklater, A., \& Suganami, H. (2006).The English school of international relations: A contemporary reassessment.(Vol. 102). Cambridge University Press.

[42] Maiworm, F. (2001). ERASMUS: continuity and change in the 1990s.European journal of education,36(4), 459-472.

[43] Miller, D. (1999). Bounded citizenship. In Cosmopolitan citizenship (pp. 60-80). Palgrave Macmillan UK.

[44] Mitchell, K. (2012). Student mobility and European Identity: Erasmus Study as a civic experience?. Journal of Contemporary European Research, 8(4). 
[45] Mitchell, K. (2014). Transnational Contact and European Identity: Identity-Formation during the Erasmus Exchange?. In 21st International Conference of Europeanists. Ces.

[46] Morais, D. B., \& Ogden, A. C. (2011). Initial development and validation of the global citizenship scale. Journal of studies in international education, 15(5), 445-466.

[47] Muetzelfeldt, M., \& Smith, G. (2002). Civil society and global governance: the possibilities for global citizenship.Citizenship studies, 6(1), 55-75.

[48] Mutlu, S., Alacahan, O., \& Erdil, M. (2010). Comparison of the personal and cultural change taking place between EU Erasmus students and Turkish Erasmus students (within the sample of Adam Mickiewicz University in city of Poznan, Poland).Eurasian Journal of Anthropology,1(1), $33-43$.

[49] Neff, S. C. (1999). International law and the critique of cosmopolitan citizenship. In Cosmopolitan Citizenship (pp. 105-119). Palgrave Macmillan UK.

[50] Nussbaum, M. (1997) 'Kant and Cosmopolitanism'. in Perpetual peace: essays on Kant's cosmopolitan ideal, 25-57.

[51] Oğurlu, E. (2007) Reconstruction Of National Identites And Citizenship In The Context Of The Eu Membership: Hungary, Poland And The Czech Republic, Doctoral dissertation, Marmara University, İstanbul

[52] Osler, A., \& Vincent, K. (2004). Citizenship and the challenge of global education, British Journal of Educational Studies,52 (1),91-93 (2004)

[53] Önder, K. R., \& Balci, A. (2010). Erasmus öğrenci öğrenim hareketliliği programının 2007 yılı programdan yararlanan Türk öğrencileri üzerindeki etkileri. Ankara Avrupa Çalışmaları Dergisi, $9(2), 93$

[54] Özkırımlı, U. (2008).Milliyetçilik ve Türkiye-AB ilişkileri, (Vol. 6). TESEV Yayınları.

[55] Papatsiba, V. (2009). European higher education policy and the formation of entrepreneurial students as future European citizens. European Educational Research Journal,8(2), 189-203.

[56] Perry, L., Stoner, K. R., Stoner, L., Wadsworth, D., Page, R., \& Tarrant, M. A. (2016). The importance of global citizenship to higher education: The role of short-term study abroad. Cambridge Journal of Education and Science, 754.

[57] Pike, G. (2000). Global education and national identity: In pursuit of meaning. Theory Into Practice, 39 (2), 64-73

[58] Robertson, R. (1992).Globalization: Social theory and global culture .(Vol. 16). Sage.

[59] Samra, Mandeep (2007), Creating Global Citizens 'The Case of Connecting Classrooms', Master dissertation, London School of Economics.

[60] Sari, Onur E. (2014). Role of Common Education Policies of The European Union in Europeanization Process: Erasmus Exchange Programme, Master dissertation, Marmara University, İstanbul

[61] Sassen, S. (2002). Towards post-national and denationalized citizenship in Handbook of citizenship studies, 277-292.

[62] Schattle, H. (2009). Global citizenship in theory and practice in The handbook of practice and research in study abroad: Higher education and the quest for global citizenship, 3-20.

[63] Standish, A. (2014). What is global education and where is it taking us?.Curriculum Journal,25(2), 166-186

[64] Sutton, R. C., \& Rubin, D. L. (2004). The GLOSSARI Project: Initial Findings from a SystemWide Research Initiative on Study Abroad Learning Outcomes. Frontiers: The Interdisciplinary Journal of Study Abroad, 10, 65-82. 
[65] Soysal, Y. N. (1998). Toward a postnational model of membership. The Citizenship Debates, 189-217.

[66] Stevens, J. P. (2012).Applied multivariate statistics for the social sciences. Routledge.

[67] Tambini, D. (2001). Post-national citizenship. Ethnic and racial studies, 24(2), 195-217.

[68] Turner, B. S. (1997). Citizenship studies: a general theory.Citizenship studies, 1(1), 5-18.

[69] Üre, Rahmi K. (2010). Yeni Avrupanın Oluşumu ve Erasmus, Master dissertation,, Hacettepe University, Ankara

[70] Van Mol, C. (2009).The Influence of European Student Mobility on European Identity and subsequent migration aspirations. A Theoretical Framework on European Student Mobility' Working paper No. 1 Universiteit Antwerpen.

[71] Wilson, I. (2011). What should we expect of 'Erasmus generations'?.JCMS: Journal of Common Market Studies,49(5), 1113-1140.

\section{Authors}

Kadir Karatekin, Assoc.Prof. Dr., Kastamonu University, Kastamonu, Turkey, kkaratekin@kastamonu.edu.tr

Muhammed Hayati Taban, Lecturer, Kastamonu University, Kastamonu, Turkey, htaban@kastamonu.edu.tr

\section{Acknowledgement}

This research has been supported by Kastamonu University Scientific Research Projects Coordination Department. Project Number: KÜ-BAP01/2015 
